\title{
Separated at Birth: An Inquiry on the Conceptual Independence of the Entrepreneurship and the Leadership Constructs
}

\author{
Richard C. Becherer \\ Mark E. Mendenhall \\ Karen Ford Eickhoff
}

\begin{abstract}
7 ntrepreneurship and leadership may flow from the 7 same genealogical source and the appearance of 1 separation of the two constructs may be due to differences in the contexts through which the root phenomenon flows. Entrepreneurship and leadership are figuratively different manifestations of the need to create. To better understand the origin of entrepreneurship and leadership, research must first focus on the combinations or bierarchy of traits that are necessary, but perbaps not sufficient, to stimulate the two constructs. Factors that trigger a drive to create or take initiative within the individual in the context of a particular circumstance should be identified, and the situational factors that move the individual toward more traditional leader or classic entrepreneurial-type behaviors need to be understood.
\end{abstract}

Scholars in the area of entrepreneurship have traditionally conducted their research independently and largely without awareness of their colleagues' research in the field of leadership. However, scholars have recently begun to explore linkages between the two literatures, focusing on: (1) the comparison of the stages of evolution between the two fields (Cogliser and Brigham 2004); (2) a theoretical and empirical convergence and overlap between the two literatures (Baron 2002; Cogliser and Brigham 2004); (3) field thematic evidence that entrepreneurship can be subsumed within the field of leadership (Vecchio 2003); (4) the mutually beneficial effects of an integration of the two literatures (Baron 2002; Cogliser and Brigham 2004; Gartner, Bird, and Starr 1992; Vecchio 2003); and (5) the merging of concepts from both fields in the development of a new, universal construct, "entrepreneurial leadership" (Gupta, MacMillan, and Surie 2004; Schulz and Hofer 1999).

The purpose of this article is to add to the growing but nascent body of literature that explores the theoretical and empirical relationships between the fields of entrepreneurship and leadership. In so doing, however, our conclusions from our review of the conceptual overlaps between the literatures take a different path than our colleagues' assessments (Baron 2002; Cogliser and Brigham 2004; Gupta, MacMillan, and Surie 2004; Vecchio 2003). We will argue, after comparing the overlap of variables that have been found to influence the manifestation of entrepreneurial and leadership behavior on the part of individuals, that entrepreneurship and leadership are not overlapping constructs but are in fact separate manifestations of a deeper, core phenomenon.

First, we delineate the variables that influence entrepreneurs and leaders to exhibit behavior that scholars have found to evidence entrepreneurship or leadership. Like Cogliser and Brigham (2004) we focused our analysis of the literature on "entrepreneurs and not entrepreneurship [and leaders and not leadership] research in toto" (2004, p. 774). We also delineate variables that may influence either the behavior of entrepreneurs or of leaders while remaining dormant in their valence for the other field. Based on this review, we then explore the implications of our findings for future theoretical and conceptual direction for both fields.

\section{Variables that Influence the Manifestation of Entrepreneur and Leader Behavior}

Before we delineate the variables that influence entrepreneurs and leaders, it is important to assess the domain we focused our review within in terms of construct operationalization. Both entrepreneurship and leadership are business activities that are difficult to define in terms of snapshot descriptions. The problem in the operationalization of the leadership construct lies in the multidimensionality of the construct.Traits, behavior, influence, interaction patterns, role relationships, positional authority, power, etc. are some of the many aspects of leadership that scholars have used as foundations on which to form definitions of the construct of leadership (Yukl 1998). Scholars have found that the ability to construct a robust model of leadership lessens as greater numbers of its dimensions are incorporated into a model. Thus, in an effort to increase conceptual precision among the relationships between variables in their models, scholars have opted to create "conceptually limited" leadership models (Yukl 1998).Also, terminology is confusing when attempting a review of this field, for the terms manager and leader, depending on how they are operationalized by specific scholars may not reflect valid reflections of the actual phenomenon-leadership. Thus, Yukl (1998) and others include studies that investigated managers and executives under the umbrella of leadership studies. 
In the field of entrepreneurship, Hull, Bosley, and Udell (1980) use a classic dictionary definition to define an entrepreneur as "a person who organizes and manages a business undertaking assuming the risk for the sake of profit." Other authors simply define entrepreneurship based on the end result: a new business venture being created (Vesper 1982; Timmons, Smollen, and Dingee 1985; Begley and Boyd 1987; and Gartner 1988). One of the earliest and most renowned writers on the subject, Joseph Schumpeter, stated, “. . . entrepreneurship, as defined, essentially, consists in doing things that are not generally done in the ordinary course of business routine, it is essentially a phenomenon that comes under the wider aspect of leadership" (1934, p. 254).

An additional debate focuses on the scope of analysis in understanding entrepreneurial behavior. Shaver and Scott (1991) support the traditional approach of examining individual traits to explain entrepreneurial behavior. Other research suggests that person-centric approaches do not adequately explain entrepreneurial activity (Gartner 1988; Eckhardt and Shane 2003; McMullen and Shepherd 2006). While a trait-oriented approach alone may not provide a comprehensive explanation for entrepreneurial activity, certain traits have been identified with individuals who are entrepreneurial. Traits are associated with the entrepreneurial profile, but traits alone do not directly link to behavior.The entrepreneurship literature reflects the same difficulty that the field of leadership has had in wrestling with operationalization and construct issues (Brockhaus and Horwitz 1985; Gartner 1988).

Despite these challenges, findings do exist in both literatures that shed light on variables important to the manifestation of entrepreneur and leader behaviors. It is within this realm of "construct flexibility" that we report the results of our review of both literatures under the premise that while individual traits and expectations may not wholly explain the phenomena, they do play an important role in the triggering and maintenance of individual entrepreneur and leader behaviors.

Within the field of leadership there have been many reviews that assess variables associated with leadership (see for example, Bass 2000; Yukl 1998, 2002); we focused on the common, main findings of previous reviewers of this literature in reporting the major variables that influence leader behavior.The entrepreneurship literature is not as vast as the leadership literature and reflects few attempts to distill variables that influence entrepreneurs in meaningful ways. Thus, we reviewed the extant empirical literature in this area and we report our findings as they contrast to those of the major reviews in the leadership literature. The results of our review are summarized in Table 1.

\section{Vision}

Many scholars have noted that vision is a critical dimension to leadership effectiveness (Bass 2000; Bennis and Nanus
1985; Rainey and Watson 1996; Roy 1990/1991). The ability to define a clear mission, communicate it, and persuade others to join in the quest of its achievement is a common topic in both the empirical and theoretical leadership literature (Cogliser and Brigham 2004). Vision generally is viewed as being important because it creates a passion among the followers of the leader as well as heightened commitment and internal identification of the task in employees (Austin et al. 1996; Bass 2000; Behling and McFillen 1996; Conger and Kanugo 1987; Joplin and Daus 1997; Kanter 1989; Leavitt 1986; Rost 1993).

Similarly, vision has been found in the entrepreneurship literature to be a core dimension of effective entrepreneurs (Baum and Locke 2004; Baum, Locke, and Kirkpatrick 1998; Bryant 2004; Carland, Carland, and Stewart 1996; Cogliser and Brigham 2004; Dyer 1997; Kets de Vries 1997). Baum et al. (1998) found that the dimensional attributes of a cogent vision directly influenced subsequent success in entrepreneurial ventures. The sense of vision in entrepreneurs is necessary to create the passion that is critical in creating a new product, service, or company (Goodman 1994; Oneal 1993). Without a sense of vision, entrepreneurs find it difficult to envision alternative scenarios, and to have the imagination necessary to solve complex and perplexing problems (Goodman 1994). Entrepreneurs and leaders with a strong sense of vision are often viewed by others as being charismatic in their behavior by both leadership (Bass 1985; 2000; Conger and Kanugo, 1988, 1998; Rainey and Watson 1996) and entrepreneurship scholars (Baum and Locke 2004; Dyer 1997; Kets de Vries 1997). Interestingly, there is a strong counter-literature that suggests that charisma often plays a negative role in terms of the long-term success of organizations (for example, see Collins 2001). Sustainability of vision requires a "systemization" or an "infusion of values" (Selznick 1957) into the organization and charisma rarely leads to "shared vision," but rather "projected vision." While the jury is still out on the exact nature of the role charisma plays in effective entrepreneurial and leader effectiveness, our review nevertheless reflects that people tend to attribute charisma to individuals who have a vision and work to carry it out.

\section{Creativity/Innovation}

Creativity has been cited as a characteristic of leadership, particularly among transformational leaders (Bass 1985). Leaders tend to be more creative, to have novel and innovative ideas, and to be less inhibited as they search for ideational solutions. Similarly, curiosity has been found to be a critical component of leadership effectiveness in global contexts (Black, Morrison, and Gregersen 1999). Among the personal attributes that predicted managerial advancement over a 20-year time period at AT\&T, creativity was one of the primary predictors (Howard and Bray 1990). Also, creativity is necessary to 
Table 1. Constructs and Research by Disciplinary Area-Review of Empirical Literature

\begin{tabular}{|c|c|c|}
\hline Variables & Leadership Literature & Entrepreneurship Literature \\
\hline Vision & $\begin{array}{l}\text { Bass } 2000 \\
\text { Bennis and Nanus } 1985 \\
\text { Rainey and Watson } 1996 \\
\text { Roy 1990/1991 } \\
\text { Cogliser and Brigham, } 2004 \\
\text { Austin et al. 1996 } \\
\text { Behling and McFillen } 1996 \\
\text { Conger and Kanugo } 1987 \\
\text { Joplin and Daus } 1997 \\
\text { Kanter } 1989 \\
\text { Leavitt } 1986 \\
\text { Rost } 1993 \\
\text { Bass } 1985 \\
\text { Conger and Kanugo, 1988, } 1998\end{array}$ & $\begin{array}{l}\text { Baum and Locke } 2004 \\
\text { Baum, Locke, and Kirkpatrick } 1998 \\
\text { Bryant } 2004 \\
\text { Carland, Carland, and Stewart } 1996 \\
\text { Cogliser and Brigham, } 2004 \\
\text { Dyer } 1997 \\
\text { Kets de Vries } 1997 \\
\text { Goodman } 1994 \\
\text { Oneal } 1993\end{array}$ \\
\hline $\begin{array}{l}\text { Creativity/ } \\
\text { Innovation }\end{array}$ & $\begin{array}{l}\text { Bass } 1985 \\
\text { Black, Morrison, and Gregersen } 1999 \\
\text { Howard and Bray } 1990 \\
\text { Mumford et al. } 2002\end{array}$ & $\begin{array}{l}\text { Carland, Hoy, Boulton, and Carland } 1984 \\
\text { Dalglish } 2000 \\
\text { Gartner } 1988 \\
\text { Hornaday and Aboud } 1971 \\
\text { Hornaday and Bunker } 1970 \\
\text { Hull, Bosley, and Udell } 1980 \\
\text { Jennings, Cox, and Cooper } 1994 \\
\text { Schumpeter 1934 } \\
\text { Stewart, Watson, Carland, and Carland } 1999 \\
\text { Timmons } 1999 \\
\text { Drucker } 1998\end{array}$ \\
\hline $\begin{array}{l}\text { Achievement- } \\
\text { Orientation }\end{array}$ & $\begin{array}{l}\text { Bass } 2000 \\
\text { McClelland and Burnham } 1994 \\
\text { Behling and McFillen } 1996 \\
\text { Howard and Bray } 1990 \\
\text { Yukl } 1998\end{array}$ & $\begin{array}{l}\text { Begley and Boyd } 1987 \\
\text { Brockhaus } 1982 \\
\text { Dalglish } 2000 \\
\text { Gartner } 1988 \\
\text { Hornaday and Aboud } 1971 \\
\text { Hornaday and Bunker } 1970 \\
\text { Hull, Bosley, and Udell } 1980 \\
\text { Jennings, Cox, and Cooper } 1994 \\
\text { Komives } 1972 \\
\text { Lachman } 1980 \\
\text { Liles } 1974 \\
\text { McClelland } 1961 \\
\text { Schrage } 1965 \\
\text { Shaver } 1995 \\
\text { Stewart, Watson, Carland, and Carland } 1999 \\
\text { Begley and Boyd } 1987\end{array}$ \\
\hline Tenacity & $\begin{array}{l}\text { Stogdill } 1948 \\
\text { Lussier and Achua } 2004 \\
\text { Bass 1985, 1990, } 2000 \\
\text { Behling and McFillen } 1996 \\
\text { Bennis and Nanus } 1985 \\
\text { Howard and Bray } 1990 \\
\text { Joplin and Daus } 1997 \\
\text { Stogdill } 1974\end{array}$ & $\begin{array}{l}\text { Baum and Locke } 2004 \\
\text { Hisrich and O'Brien } 1981 \\
\text { Gartner } 1988 \\
\text { Goodman } 1994 \\
\text { Hull, Bosley, and Udell } 1980 \\
\text { Markman and Baron } 2003 \\
\text { Mescon and Montanari } 1981 \\
\text { Oneal } 1993 \\
\text { Sexton and Bowman } 1985 \\
\text { Timmons and Spinelli } 2004\end{array}$ \\
\hline
\end{tabular}


(Table 1 continued)

\begin{tabular}{|c|c|c|}
\hline Self-Confidence & $\begin{array}{l}\text { Stogdill 1948, } 1974 \\
\text { Lussier and Achua } 2004 \\
\text { Behling and McFillen } 1996 \\
\text { Austin et al. } 1996 \\
\text { House } 1977 \\
\text { House and Baetz } 1979 \\
\text { Howard and Bray } 1990\end{array}$ & $\begin{array}{l}\text { Baum and Locke } 2004 \\
\text { Boyd and Vozikis } 1994 \\
\text { Chen, Greene, and Crick } 1998 \\
\text { Gartner } 1988 \\
\text { Hornaday and Bunker } 1970 \\
\text { Hornaday and Aboud } 1971 \\
\text { Scherer, Adams, Carley, and Wiche } 1989 \\
\text { Sexton and Bowman } 1985 \\
\text { Welsh and White } 1983 \\
\text { Markman and Baron } 2003 \\
\text { Bandura } 1977 \\
\text { Baum } 1994\end{array}$ \\
\hline $\begin{array}{l}\text { Power- } \\
\text { Orientation }\end{array}$ & $\begin{array}{l}\text { Behling and McFillen } 1996 \\
\text { Conger and Kanugo } 1987 \\
\text { McClelland and Burnham 1976, } 1994 \\
\text { Yukl } 1998 \\
\text { Howard and Bray } 1990\end{array}$ & $\begin{array}{l}\text { Dalglish } 2000 \\
\text { Gartner } 1988 \\
\text { Hornaday and Aboud } 1971 \\
\text { Schrage } 1965 \\
\text { Hagen } 1962 \\
\text { Collins, Moore, and Unwalla } 1964 \\
\text { Shapero } 1975 \\
\text { McGrath, MacMillan, and Scheinberg } 1992 \\
\text { Gerber } 1988\end{array}$ \\
\hline Proactivity & $\begin{array}{l}\text { Bateman and Crant } 1993 \\
\text { Bass } 1985 \\
\text { Barker } 1997 \\
\text { Kotter } 1996 \\
\text { Kets de Vries } 1997 \\
\text { Tracey } 1998 \\
\text { Berry, Seiders, and Gresham } 1997\end{array}$ & $\begin{array}{l}\text { Becherer and Maurer } 1999 \\
\text { Timmons and Spinelli } 2004\end{array}$ \\
\hline Risk-taking & $\begin{array}{l}\text { Austin et al. } 1996 \\
\text { Berry, Seiders, and Gresham } 1997 \\
\text { Kets de Vries } 1997 \\
\text { Tracey } 1998 \\
\text { Howard and Bray } 1990\end{array}$ & $\begin{array}{l}\text { Begley and Boyd } 1987 \\
\text { Brockhaus 1980, } 1982 \\
\text { Carland, Hoy, Boulton, and Carland } 1984 \\
\text { Dalglish } 2000 \\
\text { Gartner } 1988 \\
\text { Hornaday and Bunker } 1970 \\
\text { Hull, Bosley, and Udell } 1980 \\
\text { Kao 1991 } \\
\text { Liles } 1974 \\
\text { Litzinger } 1965 \\
\text { Mancuso } 1975 \\
\text { McClelland 1961 } \\
\text { Oneal 1993 } \\
\text { Palmer 1971 } \\
\text { Sexton and Bowman 1985 } \\
\text { Stewart and Roth 2001 } \\
\text { Stewart, Watson, Carland, and Carland } 1999 \\
\text { Timmons 1999 } \\
\text { Welsh and White 1981 } \\
\text { Schere 1982 } \\
\text { McGrath, MacMillan, and Scheinberg } 1992 \\
\text { Vecchio 2003 }\end{array}$ \\
\hline Locus of Control & $\begin{array}{l}\text { Yukl } 2002 \\
\text { Begley and Boyd } 1987 \\
\text { Miller, Kets de Vries, and Toulouse } 1982 \\
\text { Miller and Toulouse } 1986 \\
\text { Howell and Avolio } 1993\end{array}$ & $\begin{array}{l}\text { Brockhaus } 1980 \\
\text { Borland } 1975 \\
\text { Brockhaus and Nord } 1979 \\
\text { Dalglish } 2000 \\
\text { Gartner } 1988 \\
\text { Hull, Bosley, and Udell } 1980 \\
\text { Liles } 1974 \\
\text { Shaver } 1995 \\
\text { Timmons } 1999 \\
\text { Brockhaus } 1982 \\
\text { Vecchio } 2003 \\
\text { Carland, Carland, and Stewart } 1996\end{array}$ \\
\hline
\end{tabular}


lead creative people in R\&D and innovation contexts because multiple permutations of direct and indirect influence tactics are required in such work settings (Mumford et al. 2002).

Not surprisingly, creativity/innovation is a common manifestation of entrepreneurship and is well established in the empirical literature of that field (Carland et al. 1984; Dalglish 2000; Gartner 1988; Hornaday and Aboud 1971; Hornaday and Bunker 1970; Hull, Bosley, and Udell 1980; Jennings, Cox, and Cooper 1994; Schumpeter 1934; Stewart et al. 1999; Timmons 1999). Drucker (1998) observes that entrepreneurship is marked by an individual's commitment to the systematic practice of innovation. Further evidence that creativity and innovation are an inherent aspect of entrepreneurship was identified in research by Carland et al. (1984) as they found that innovation was the critical factor that distinguished entrepreneurs from managers and small businessowners. The entrepreneur appears to have a propensity for "creating activity" manifested by some innovative combination of resources for profit.

\section{Achievement-Orientation}

Bass (2000), in his review of the leadership literature, observed that need and concern for achievement is evidenced by leaders, and McClelland and Burnham (1994) found that a high need for achievement is necessary for managers to be successful in decentralized companies. They noted that "a constant concern for improvement, for growing the business in a cost-efficient way, characterizes successful managers of small companies" (p. 10). Behling and McFillen (1996) found that leaders have active attitudes toward goal attainment, and Howard and Bray (1990) found that achievement orientation predicted long-term managerial advancement. The empirical research on achievement orientation in leadership does reflect mixed findings however (Yukl 1998).

The high need for achievement has been demonstrated to be a clear variable in entrepreneurship within the literature of that field (Begley and Boyd 1987; Brockhaus 1982; Dalglish 2000; Gartner 1988; Hornaday and Aboud 1971; Hornaday and Bunker 1970; Hull, Bosley, and Udell 1980; Jennings, Cox, and Cooper 1994; Komives 1972; Lachman 1980; Liles 1974; McClelland 1961; Schrage 1965; Shaver 1995; Stewart et al. 1999). Entrepreneurs are active as opposed to passive decision-makers, and they tend to be goal setters. They compete with their own standards of performance and generally are always attempting to improve their performance (Begley and Boyd 1987). As part of their achievement orientation, entrepreneurs often seek feedback on how they are doing to continue to improve performance.

\section{Tenacity}

Tenacity, perseverance, drive, high levels of endurance-this orientation has been labeled with a variety of terms in both the entrepreneurship and leadership literature, but we will use the term "tenacity" for the purposes of this article. The leadership literature from the earliest stages of the field's development to the present is replete with the emergence of tenacity as being correlative of leadership behavior, or manifested whenever leadership behavior is observed. Tenacity to succeed in achieving one's vision or mission has come to be seen as a critical component of leadership effectiveness (Bass 1985, 1990, 2000; Behling and McFillen 1996; Bennis and Nanus 1985; Howard and Bray 1990; Joplin and Daus 1997; Lussier and Achua 2004; Stogdill 1948, 1974).

In the entrepreneurship literature, tenacity is well documented as being a hallmark of the entrepreneur (Baum and Locke 2004; Hisrich and O'Brien 1981; Gartner 1988; Goodman 1994; Hull, Bosley, and Udell 1980; Markman and Baron 2003; Mescon and Montanari 1981; Oneal 1993; Sexton and Bowman 1985). An entrepreneur needs tenacity, commitment, and determination to overcome obstacles and compensate for other weaknesses or resource shortages. This characteristic was emphasized by President Calvin Coolidge who was said to have stated: "Nothing in the world can take the place of persistence. Talent will not; nothing is more common than unsuccessful men with talent. Genius will not; unrewarded genius is almost a proverb. Education will not; the world is full of educated derelicts. Persistence and determination alone are omnipotent. The slogan 'Press On' has solved and always will solve the problems of the human race" (Respectfully Quoted 2003).

In fact, in entrepreneurial pursuits, commitment and determination have been cited as the most important factors for success (Timmons and Spinelli 2004). Similarly, Hisrich and O'Brien (1981) cite perseverance as a critical success factor in their study of female entrepreneurs. Hull, Bosley, and Udell (1980) found "persistence" as underlying the success of the entrepreneurs in their study. While Gartner (1988) prefers the notion of activities or behaviors rather than traits, he also supports the importance of perseverance as an important aspect of entrepreneurship.

\section{Self-confidence}

Self-confidence has also emerged as a factor associated with leadership from the earliest studies to the present (Stogdill, 1948, 1974; Lussier and Achua 2004).A self-assured individual (Behling and McFillen 1996) with a strong belief that what he/she is doing is right (Austin et al. 1996; Behling and McFillen 1996; House 1977; House and Baetz 1979) has a strong positive impact on followers. Self-confidence was one of the predictors of managerial advancement over a 10-year time span in Howard and Bray's longitudinal study done at AT\&T (1990).

Similarly, self-confidence seems to be integral to the pursuit of entrepreneurship as well (Baum and Locke 2004; Boyd 
and Vozikis 1994; Chen, Greene, and Crick 1998; Gartner 1988; Hornaday and Bunker 1970; Hornaday and Aboud 1971; Scherer et al. 1989; Sexton and Bowman 1985; Welsh and White 1983). Research has demonstrated that entrepreneurs are self-confident, particularly when they are in control. There is some gain or loss in their self-confidence, however, when there is a gain or loss in control (Welsh and White 1983). The role of self-confidence in entrepreneurship was supported by the empirical work of Sexton and Bowman (1985) who found that, compared with others, entrepreneurs prefer autonomy in terms of self-reliance, dominance, and independence. Markman and Baron (2003) have isolated the variable of self-efficacy - "the belief in one's ability to muster and implement necessary resources, skills and competencies to attain a certain level of achievement on a given task" (Shane, Locke, and Collins 2003, p. 267; Bandura 1977), as a predictor of starting new ventures on the part of entrepreneurs, while Baum (1994) found it was a robust predictor of actual growth of start-ups. Baum and Locke (2004), in a sixyear longitudinal study, found that self-efficacy combined with the variables of goals and communicated vision had direct effects on new venture growth.

\section{Power-Orientation}

Both entrepreneurs and leaders appear, from the empirical literature, to be comfortable with the notion and process of power acquisition (Behling and McFillen 1996; Conger and Kanugo 1987; McClelland and Burnham 1976, 1994; Yukl 1998). Stogdill (1948) observed that one of the paramount traits of leaders was "the desire to accept responsibility and occupy a position of dominance and control" (Yukl 1998, p. 236). A subsequent review by Stogdill in 1974 confirmed this trait as being correlative to leadership behavior. Howard and Bray (1990) found that need for power (dominance) was a strong predictor of managerial advancement in their longitudinal study of AT\&T managerial cadres. This need for power can be deployed for selfish reasons (career advancement, dominance, manipulation, etc.) or for reasons that flow out of what McClelland and Burnham (1976) termed, "socialized power" (desire to build a productive team, develop people, etc.). Thus, the mere possession of a high need for power does not predict in and of itself behavior that would lead to sustainable organizational success.

Entrepreneurs also tend to exhibit a need for power and control (Dalglish 2000; Gartner 1988; Hornaday and Aboud 1971; Schrage 1965), but perhaps with slightly different motives.An entrepreneur's need for power is often driven by inability to accept authority (Hagen 1962), a negative experience or general dissatisfaction with previous work (Collins, Moore, and Unwalla 1964; Shapero 1975), or they are first and foremost "technicians" who are better at doing what their business does than anyone else (Gerber 1988). These entre- preneurs want to retain control as they think more about the work of the business than running the business as the owner/entrepreneur. Moreover, McGrath, MacMillan, and Scheinberg (1992) point out that entrepreneurship is one route to mobility and a higher societal position, and entrepreneurial activities can produce an advantage that can be obtained in no other way. Thus, via their entrepreneurial activities entrepreneurs are likely to promote a greater amount of differentiation between themselves and others.

\section{Proactivity}

Bateman and Crant (1993, p. 105) define the proactive individual as one who in relative terms is not constrained by the situation and who causes environmental change. Bass (1985) noted that leaders are proactive in their thinking, are less willing to accept the status quo, and are more likely to seek new ways of doing things. One of the paramount differentiating variables between leaders and others is that they desire to and are willing to launch change initiatives based on their sense of vision and mission for the organization (Barker 1997; Kotter 1996). They are receptive to new ways of doing things (Kets de Vries 1997; Tracey 1998) and are willing to "break the rules" to do so (Berry, Seiders, and Gresham 1997).

Proactivity has been identified in the entrepreneurial literature as a key trait at the interface between the entrepreneur's individual orientation and his/her view of the environment (Becherer and Maurer 1999). Becherer and Maurer (1999) found that more proactive individuals tend to start more businesses. In this context, entrepreneurialism is an action-oriented behavior that reflects the way entrepreneurs approach the opportunities that they identify. Timmons and Spinelli (2004) stress that entrepreneurs pursue opportunity regardless of the resources they control and that they do not feel constrained by situational forces.

\section{Risk-taking}

Because leadership involves leading people toward the achievement of a new state of affairs that is embodied in the mission or vision, leaders are by nature involved in risky ventures (Kotter 1996). Risk-averse individuals rarely emerge as leaders in the leadership research literature (Austin et al. 1996; Berry, Seiders, and Gresham 1997; Kets de Vries 1997; Tracey 1998). The high need for security was negatively correlated with managerial advancement (Howard and Bray 1990).

Risk-orientation has long been seen as being important to the emergence of entrepreneurs and has been studied extensively by scholars in this field (Begley and Boyd 1987; Brockhaus 1980, 1982; Carland et al. 1984; Dalglish 2000; Gartner 1988; Hornaday and Bunker 1970; Hull, Bosley, and Udell, 1980; Kao 1991; Liles 1974; Litzinger 1965; Mancuso 1975; McClelland 1961; Oneal 1993; Palmer 1971, Sexton and 
Bowman 1985; Stewart and Roth 2001; Stewart et al. 1999; Timmons 1999; Welsh and White 1981). Managing the uncertainties of risk has been shown to be critical for effective entrepreneurship; for example, Oneal (1993) found that entrepreneurs, compared to others, possess an innate ability to compartmentalize their fears and doubts as they go forward in ventures that are associated with high risk.

Similarly, entrepreneurs were found to possess higher levels of tolerance of uncertainty (Begley and Boyd 1987; Gartner 1988; Hornaday and Bunker 1970; Schere 1982; Sexton and Bowman 1985) and lower levels of uncertainty avoidance (McGrath, MacMillan, and Scheinberg 1992) compared to nonentrepreneurs. While many findings support risk-taking as a variable influencing entrepreneurship, some studies have not found significant differences between entrepreneurs and other samples (for a review, see Vecchio 2003). In an attempt to "overcome the limitations of narrative reviews" in this literature, Stewart and Roth (2001) conducted a meta-analysis of the risk-taking/entrepreneurship literature and found that the "risk propensity of entrepreneurs is greater than that of managers. Moreover, there are larger differences between entrepreneurs whose primary goal is venture growth versus those whose focus is on producing family income" (2001, p. 145). Stewart and Roth's 2001 conclusions thus provide important evidence that entrepreneurs, like leaders, are more risk tolerant than traditional managers.

\section{Locus of Control}

Yukl (2002) in his review of the leadership literature observed, "... research on the relationship of this trait to managerial effectiveness is still limited, but the results suggest that a strong internal locus of control orientation is positively associated with managerial effectiveness." (p. 186) Locus of control refers to the individual's perceived ability to influence events in his/her life. Persons at the "internal" end of the continuum believe in the effectiveness of their own actions, and discount the impact of "external" factors such as destiny or luck (Begley and Boyd 1987). Pioneer studies that have produced solid evidence for this assertion include Miller, Kets de Vries, and Toulouse (1982), Miller and Toulouse (1986), and Howell and Avolio (1993). In the latter study, it was found that executives who are high on internal locus of control produced better business-unit performance than executives scoring high on external locus of control.

Locus of control has been a focus of more research in the entrepreneurship field than in the field of leadership (Brockhaus 1980; Borland1975; Brockhaus and Nord 1979; Dalglish 2000; Gartner 1988; Hull, Bosley, and Udell 1980; Liles 1974; Shaver 1995; Timmons 1999). Internal control locus has been demonstrated to be correlated with a high achievement orientation among entrepreneurs (Brockhaus 1982). This is consistent with the concept that the internality of high achievers allows them to believe that they can in fact affect outcomes. Some research, however, has indicated that locus of control is not useful in discriminating between entrepreneurs and managers (for a review, see Vecchio 2003). Both entrepreneurs and managers appear to be higher on internality than the general population but not significantly different from one another (Carland, Carland, and Stewart 1996).

\section{Conceptual Overlaps}

Both literatures also evidence other conceptual overlaps that are less glaring and substantial than those discussed above. For example, both entrepreneurs and leaders tend to be future-oriented in their thinking (Austin et al. 1996; Hebert and Bass 1995; Tracey 1998). Both entrepreneurs and leaders exhibit high levels of physical energy (Bass 1990; Gartner 1988; Hornaday and Bunker 1970; Stogdill 1974) and can more readily cause and adapt to change than others (Bass 2000; Sexton and Bowman 1985; Schein 1995). Entrepreneurs and leaders both exhibit a heightened sensitivity and understanding of context and environments than others (Bass 1985; Behling and McFillen 1996; Conger and Kanugo 1987; Hornaday and Bunker 1970; Schrage 1965) as well as heightened levels of decision-making and problemsolving skills (Austin et al. 1996; Carland, Carland, and Stewart 1996; Hosking and Morley 1988; Rost 1993).

\section{Discussion}

One conclusion that can be drawn from this review is that due to significant variable overlap across the two phenomena, entrepreneurship may simply reflect leadership processes within a specific context (entrepreneurial ventures) and thus should be seen not as a separate field but rather as part of the domain of leadership; that is, entrepreneurial behavior is simply leadership behavior enacted in a unique context (Vecchio 2003).Another reasonable conclusion that can be drawn from the review is that while entrepreneurial behavior reflects conceptual similarity with leader behavior, perhaps enough of a difference of degree is manifested (possibly due to context and other factors) that treating entrepreneurs as a separate category from leaders is warranted. Each of these two conclusions naturally generates implications for both fields in terms of research direction, strategic guidance of the field by primary scholars, and the training of doctoral students (Baron 2002; Cogliser and Brigham 2004; Vecchio 2003).

Another new construct that has recently evolved from an analysis of the two fields is a style of contemporary leadership termed "entrepreneurial leadership" (Gupta, MacMillan, and Surie 2004; Fernald, Solomon, Taradishy 2005). While the entrepreneurial leadership construct provides another perspective on effective leadership among entrepreneurs and managers, it simply attempts to blend the best of both constructs. The construct of entrepreneurial leadership over- 
looks the unique aspects of both entrepreneurship and leadership in an attempt to explain higher than expected leader performance in modern organizations through entrepreneurial thinking and entrepreneurs who are particularly successful in leading start-up organizations.

However, it is also possible that both entrepreneurial behavior and leader behavior are manifestations of a more fundamental construct. Rather than entrepreneurial behavior being a spoke that radiates from the hub of the leadership construct or being different enough in degree from leadership to warrant its own conceptual domain, it is possible that both entrepreneurial behavior and leader behavior are conceptual spokes that radiate from a hub representing a construct that has yet to be delineated theoretically by scholars in either field.

\section{What Causes Entrepreneurship and Leadership Behaviors?}

It may be premature to postulate the nature of the undergirding catalyst for these two phenomena, but this article suggests one direction for consideration by scholars who may undertake exploratory research in this area. It is possible that a deep, inner need or drive to "create" catalyzes entrepreneurial and leader behavior. This propensity to engage one's environment, to create something new, and to craft change within it may be the common conceptual ancestor of both entrepreneurship and leadership. A few scholars have noted this possibility in their observations regarding entrepreneurial and leader behavior (Follett 1924; Kotter 1996), but empirical study has focused more on the effects of this "creation" phenomenon rather than the core process itself as a focus of investigation and research. We conceptualize this variable that acts as a catalyst to entrepreneurial or leader behavior as the "need to create" (NCre).

\section{The Role of Context as a Filter of Need to Create}

We suggest that the spokes that attach entrepreneurial behavior and leadership behavior to their causal hub of NCre (or, in some cases as Schumpeter argued the need to "destroy" in order to "create") is influenced by context. Based on the above review we argue that entrepreneurial behavior and leader behavior are variably manifested due to context differences (on a continuum ranging from formal organization focus to opportunity focus) on the part of those who possess high levels of the variables of vision, proactivity, creativity/innovation, achievement-orientation, tenacity, self-confidence, power-orientation, risk-taking, internal locus of control, etc. Thus, we propose that the nature of the structure of individuals' organizational settings likely filters how individuals who possess creative attributes, traits, skills, or tendencies behave (see Figure 1). Such persons may be "drawn" to particular contexts as well, but the general underlying attraction would be the potential to express, design, and impact the environment rather than just "going along for the ride."

Figure 1 represents how the organizational context is reflective of a variety of factors. It is likely that the "organizational focus" orientation is strongest within formal organizations as compared with the "opportunity focused" orientation in organizations that have not been formally created. Similarly, organizations with more formalized structures are likely to be more organizationally focused, and newly formed organizations may focus more on the opportunities that are available rather than on organizational structural dimensions. Opportunity focus is spawned from flatter, more fluid organizational structures, and organizational focus is associated with more established organizations with a clearer mission and organizational goals.

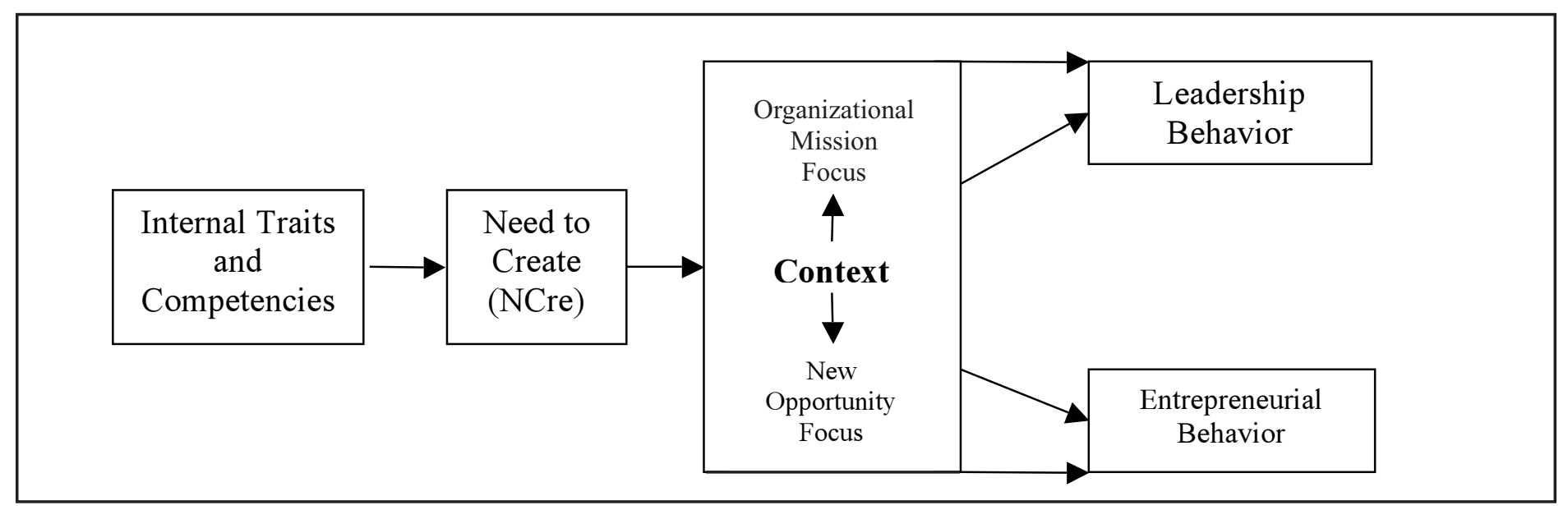

Figure 1. The Role of Internal Traits, NCre, and Context in Determining Leader/Entrepreneur Behavior 
Intuitively, practitioner-oriented treatments of leading in diverse contexts reflect the notion that though there is overlap, context filters and refracts how leadership is manifested; in fact, numerous books have been written about specific types of leadership (military leadership, ministerial leadership, corporate leadership, etc.). Similarly, entrepreneurial behavior is often practiced effectively in organizations that would not be considered start-up companies. Extraordinary efforts that vigorously pursue opportunities without regard for resources or other constraints can be found in governmental units, charitable organizations, civil organizations as well as large corporations.

Individuals high in the variables that influence both entrepreneurial and leader behavior can find themselves inside formal organizations that are highly structured and exhibit traditional bureaucratic designs, or in more informal entrepreneurial start-up organizations that exhibit flexible organizational structures, or in mixed contexts in between these two poles of the continuum (see Figure 1). The individual in a traditionally structured organization operates within the context of an organization that typically provides both position power and an extant resource base. We suggest that this type of environment elicits behavior that would generally be categorized as classic leadership (management) behavior by leadership scholars. For the individual, conversely, who operates in a context with "relative inexperience" which is more "ad hoc" or "freelance" and "resource scarce," position power is minimal. These individuals will likely exhibit behavior classified as entrepreneurial by scholars working in the entrepreneurship field.

Thus both the organization structure and extent of resource availability within which an individual enacts his/her NCre may play an important role in triggering behavior that scholars classify as being leadership or entrepreneurial in nature. Moreover, it is possible that some situations allow the individual to manifest both entrepreneurship and leadership behaviors (e.g., a progressive corporate environment) while other situations may only act as a catalyst for either leadership or entrepreneurial behavior (e.g., large, bureaucratic environments or very small start-ups). In either case, we contend that the individual likely enters the environment with a similar constellation of valences among the critical variables necessary for entrepreneurial or leadership behavior to emerge.

\section{More Questions}

This review raises more directions for future theoretical and empirical focus than those previously mentioned. For example, more attention on the part of scholars to determine if the variables that are common to entrepreneurs and leaders are equal in terms of their effect on subsequent leadership or entrepreneurship behavior, or whether they hold differing valences, would be a useful contribution to the field.To date, for example, there is no understanding of the degree of variance that vision vs. risk-taking vs. creativity account for in either entrepreneurship or leadership emergence, though some scholars are beginning to address these issues (Baum and Locke 2004).

Similarly, one might ask if the common dimensions of both constructs are products of the NCre or if they are separate dimensions extant in the individual that can be employed to stimulate creative activity once the desire exists. Certain traits, dimensions, skills, and competencies may exist within an individual as a precondition for the NCre which emerges to manifest, in the right context, entrepreneurial and leader behavior. The possibility that a deep, inner NCre can awaken after lying latent in an individual is an intriguing idea. Bennis and Thomas (2002) note that many entrepreneurs and leaders had "triggering events" in their lives that stemmed from great loss, challenge, or hardship-what they termed "crucible experiences." These experiences seem to facilitate the development of new skills or the enhancement of existing skills that in turn facilitate higher levels of entrepreneur and leader behaviors.

Thus, the NCre likely is a behavioral orientation that is catalyzed by competencies, traits, or dimensions that already exist, but lay in differing degrees of dormancy. In other cases, some individuals simply may have a constant desire to create-to form something new - that nourishes these competencies, traits, and dimensions in an on-going process of constant reciprocal reinforcement. The notion of an intervening behavioral orientation that emerges as a precursor to entrepreneurial or leadership behavior moves away from the person-centric school of thought but still gives some credence to the fact that certain traits may be a necessary but not sufficient condition for leader or entrepreneur behavior.

Additionally, little is known regarding how these variables interact with one another to stimulate leadership or entrepreneurship behaviors. For example, while vision may be a necessary condition for entrepreneurship and leadership, it may be that it is by no means a sufficient condition, (i.e., it does not, by itself, guarantee leadership or entrepreneurship emergence; Swartz 1997). While an individual may have one characteristic such as vision, can that same person enact either entrepreneurial or leader behavior if he/she has little tenacity or is averse to risk-taking? It may be that all the common dimensions act collectively as a necessary condition for entrepreneurial and leader emergence, and that no one of them-or even just a few of them-will suffice. A more sophisticated understanding of when, and under what conditions, one variable moves to figure and another to ground in the process of particular entrepreneurial and leader behavior manifestation is an area in both fields that requires more focus on the part of scholars. 


\section{Implications}

While more research and study can continue the definition and operationalization of the NCre construct, the existence of this phenomenon suggests some interesting practical implications. The notion of a "context" that filters and perhaps even acts as a catalyst for entrepreneur or leader behavior suggests that it may be possible to create contexts that will be more likely to spawn entrepreneur or leader behavior. For example, to increase the probability of productive entrepreneurial activity, the prospective entrepreneur may have to be fully committed to the pursuit of an opportunity.This commitment makes opportunity the major focus, and thus creates an organizational context which is most likely to allow entrepreneurial behavior to emerge. It is widely accepted that commitment by the entrepreneur is necessary for start-up success (Timmons and Spinelli 2004), hence part-time business startup or less than full engagement are situations less likely to spawn successful new ventures. Less commitment and less opportunity focus may mean that the NCre phenomena will remain dormant. Similarly, for leadership behavior to be more likely to emerge, a context with a clear organizational mission focus may be a prerequisite. Organizations with a vague mission or a disjointed organizational focus may stifle leadership. These less focused organizations may have employees who are capable of strong leadership, yet NCre does not emanate from these individuals because the organization culture is not a fertile context for leadership.

The middle of the context continuum represents an organizational environment where there is not a strong commitment to either opportunity or an organizational mission. In this "gray area," both entrepreneurial and leader behavior are not likely to manifest themselves. The two ends of the organizational context continuum may stimulate productive behavior, while the middle of the continuum does not have any positive effect. This may partially explain why leadership development training in large companies is so "hit and miss" in terms of its results: training people to be leaders and then sending them back into organizational contexts that neutralize their attempted leadership behaviors destroys the investment the company made in their leadership development efforts. This article suggests that leadership development efforts may be more fruitful by focusing first on the organizational context-rendering it more hospitable to leadership initiative on the part of its managers-and then deploying leadership development programs once the context is "leadership-friendly" in nature.

At the individual level, the implication of our model is that if one desires to become an entrepreneur or a leader, one must first assess the fit between the context they are in and their extant NCre orientation and skills. The latter assessment will be more difficult to accomplish than the former. More effective measures of NCre need to be developed both in terms of questionnaire assessment but also in experiential assessment by companies and by universities. The entrepreneurship and leadership literature is rife with examples of individuals to whom no one would attribute entrepreneur or leader skills, but when dramatically placed in new contexts, found that they indeed did possess skills that allowed them to be successful entrepreneurs or leaders. Developing the ability to assess and profile latent skills associated with NCre, and developing a more comprehensive understanding of how to match specific skill profiles to contexts that best "fit" the individual is an important next step in the development of entrepreneurs and leaders, and this article argues that the key to this development is the "NCre Skill/Context Match."

The relationship between NCre and context has implications for entrepreneur/leader development in the elementary and secondary educational system as well. The traditional approach to educating elementary and high school students does not reflect a context that is either opportunity- or organization-mission focused. Cognitive recall of large amounts of information, in contexts where resources cannot be accessed, is the skill that is mainly rewarded.Additionally, the ability to construct logical arguments and to communicate those arguments in writing is also a primary ability that is rewarded in the North American educational system. Creating new organizational forms and/or marshalling resources and the talents of others to enhance an existing social unit's productivity are skills that are almost entirely ignored throughout a student's sojourn in the educational system. Even when creativity or leadership is attempted to be taught, it is often taught through the lens of the primary pedagogical methods described above.

Thus, to educate future innovators and leaders, it will be necessary to change the structure and nature of the classroom context. It will be necessary to rethink pedagogy, and to develop techniques that can extract latent skills associated with NCre from students and to foster their experimentation of these skills as they surface. This implication is radical, but one that flows from the model: the reason our society does not produce more and more successful entrepreneurs and leaders is that we have not constructed an educational context wherein such development can occur.

\section{Conclusion}

We argue that entrepreneurship and leadership may flow from the same genealogical source, NCre, and that the appearance of separation of the two constructs may be due largely to differences in the contexts through which the root phenomenon flows. Just as a prism refracts light into different colors, entrepreneurship and leadership are figuratively different manifestations of a more base phenomenon, NCre. 
To better understand the origin of the constructs, more research needs to first focus on the combinations or hierarchy of traits that are necessary, but perhaps not sufficient, to stimulate leader/entrepreneurial behavior. Secondly, it is important to identify the factors that trigger a drive to create or take initiative within the individual in the context of a particular circumstance. And, thirdly it is important to gain a bet- ter understanding of the situational factors that move the individual toward either more traditional leader- or classic entrepreneurial-type behaviors. Such a line of inquiry would provide additional insight into the origin of entrepreneurial and leader behavior that currently does not exist, but which is absolutely necessary for an enhanced understanding of these two important phenomena.

\section{References}

Austin, N. K., J. Batten, J. Ryan, and G. Vega. 1996. My business needs new leadership. What should I look for? Small Business Forum 14, 3: 8-32.

Bandura,A. 1977. Self-efficacy:Toward a unifying theory of behavioral change. Psychological Review 84, $191-215$.

Barker, R.A. 1997. How can we train leaders if we do not know what leadership is? Human Relations 50, 4: 343-362.

Baron, R.A. 2002. OB and entrepreneurship: The reciprocal benefits of closer conceptual links. In B. M. Staw and R. M. Kramer, eds., Research in Organizational Behavior. Oxford, UK: Elsevier Science, 225-269.

Bass, B. M. 1985. Leadership: good, better, best. Organizational Dynamics 13, 3: 26-40.

Bass, B. M. 1990. Handbook of Leadership: A survey of theory and research. New York: Free Press.

Bass, B. M. 2000.The future of leadership in learning organizations. Journal of Leadership Studies 7, 3: 18.

Bateman,T. S., and J. M. Crant. 1993. The proactive component of organizational behavior:A measure and correlates. Journal of Organizational Behavior 14, 2: 103-118.

Baum, R. J. 1994. The relation of traits, competencies, vision, motivation, and strategy to venture growth. Unpublished doctoral dissertation, University of Maryland.

Baum, R. J., and E.A. Locke. 2004. The relationship of entrepreneurial traits, skill, and motivation to subsequent venture growth.Journal of Applied Psychology 89, 4: 587-598.

Baum, R. J., E.A. Locke, and S.A. Kirkpatrick. 1998. A longitudinal study of the relation of vision and vision communication to venture growth in entrepreneurial firms. Journal of Applied Psychology 83, 1: 43-54.

Becherer, R. C., and J. G. Maurer. 1999. The proactive personality disposition and entrepreneurial behavior among small company presidents. Journal of Small Business Management 37, 1: 28-36.

Begley,T. M., and D. P. Boyd. 1987. Psychological characteristics associated with performance in entrepreneurial firms and smaller businesses. Journal of Business Venturing 2: 79-93.

Behling, O., and J. M. McFillen. 1996.A syncretical model of charismatic/transformational leadership. Group E Organizational Management 21, 2: 163-178.

Bennis, W., and B. Nanus. 1985. Leaders: The Strategies for Taking Charge. New York: Harper and Row Publishers, Inc.

Bennis, W. G, . and R. J.Thomas. 2002. Crucibles of leadership. Harvard Business Review 80, 9: 39-45

Berry, L. L., K. Seiders, and L. G. Gresham. 1997. For love and money:The common traits of successful retailers. Organizational Dynamics 26, 2: 6-24.

Black, J. S., A. Morrison, and H. B. Gregersen. 1999. Global Explorers: The Next Generation of Leaders. London: Routledge.

Borland, C. 1975. Locus of control, need for acbievement, and entrepreneurship. Doctoral dissertation, University of Texas.

Boyd, N. G., and G. S. Vozikis. 1994. The influence of self-efficacy in the development of entrepreneurial intentions and actions. Entrepreneurship Theory and Practice 18, 63-90.

Brockhaus, R. H. 1980. Risk taking propensity of entrepreneurs. Academy of Management Journal 23, 3: 509-520.

Brockhaus, R. H. 1982. The psychology of the entrepreneur. In C.A. Kent, D.C. Sexton, and K.H. Vesper, eds., Encyclopedia of Entrepreneurship. New York: Prentice-Hall, Inc.

Brockhaus, R. H., and P. S. Horwitz. 1985. The psychology of the entrepreneur. In D. L. Sexton and R. W. Smilor, eds., The Art and Science of Entrepreneurship. Cambridge, MA: Ballinger

Brockhaus, R. H., and W. R. Nord. 1979. An exploration of factors affecting the entrepreneurial decision: Personal characteristics vs. environmental conditions. Proceedings of the Annual Meeting of Academy of Management. 
Bryant,T.A. 2004. Entrepreneurship. In G. R. Goethals, G. J. Sorrensen, and J. M. Burns, eds., Encyclopedia of Leadership, Volume 1.Thousand Oaks, CA: Sage, 442-448.

Carland, J.W., J. C. Carland, and W. H. Stewart. 1996. Seeing what's not there:The enigma of entrepreneurship. Journal of Small Business Strategy 7, 1:1-20.

Carland, J. W., F. Hoy, W. Boulton, and J. C. Carland. 1984. Differentiating entrepreneurs from small business owners: a conceptualization. Academy of Management Review 9, 2:354-359.

Chen, C.C., P. G. Greene, and A. Crick. 1998. Does entrepreneurial self-efficacy distinguish entrepreneurs from managers? Journal of Business Venturing 13: 295-316.

Cogliser, C. C., and K. H. Brigham. 2004. The intersection of leadership and entrepreneurship: Mutual lessons to be learned. Leadership Quarterly 15:771-799.

Collins, J. 2001. Good to great:Why some companies make the leap...and others don't. New York: Harper-Collins.

Collins, O. F., D. G. Moore, D. B. Unwalla. 1964. The Enterprising Man. Michigan State University Press.

Conger, J.A., and R. N. Kanugo. 1987.Toward a behavioral theory of charismatic leadership in organizational settings. Academy of Management Review 12: 637-647.

Conger, J.A., and R. N. Kanugo. 1988. The empowerment process: Integrating theory and practice. Academy of Management Review 13: 471-482.

Conger, J.A., and R. N. Kanugo. 1998. Charismatic leadership in organizations. Thousand Oaks: CA: Sage Publications

Dalglish, C. 2000. Leadership development for entrepreneurs. Paper presented at the 45th International Conference on Small Business, Queensland University of Technology, Brisbane, Australia.

Drucker, P. F. 1998. The discipline of innovation. Harvard Business Review 76, 6: 149-157.

Dyer,W. G. 1997. Organization development in the entrepreneurial firm. The Journal of Applied Behavioral Science 33, 2 : 190-208.

Eckhardt, J.T., and S.A. Shane. 2003. Opportunities and entrepreneurship. Journal of Management 29, 3:333-349.

Follett, M. P. 1924. Creative Experience. Longmans, Green.

Fernald, Jr., L.W., G.T. Solomon, and A.Tarabishy. 2005. A new paradigm: Entrepreneurial leadership. Southern Business Review 30, 2: 1-10.

Gartner,W. B. 1988. "Who is an entrepreneur?" is the wrong question. American Journal of Small Business 12, 4: 11-32.

Gartner,W. B., B. J. Bird, and J.A. Starr. 1992. Acting as if: Differentiating entrepreneurial from organizational behavior. Entrepreneurship Theory and Practice: 13-31.

Gerber, M. E., 1988. The E-Myth. New York, NY: HarperBusiness.

Goodman, J. P. 1994. What makes an entrepreneur? Inc. 16, 1: 29.

Gupta,V., I. C. MacMillan, and G. Surie. 2004. Entrepreneurial leadership: Developing and measuring a cross-cultural construct. Journal of Business Venturing 19: 241-260.

Hagen, E. E. 1962. On the theory of social change: How economic growth begins. Homewood, IL: Dorsey Press.

Hebert, F. J., and K. E. Bass. 1995. Personality types of entrepreneurs and business students: Implications for management education. Journal of Business and Entrepreneurship 7, 2: 15-27.

Hisrich, R. D., and M. O'Brien. 1981. The woman entrepreneur from a business and sociological perspective:Their problems and needs. In K. H.Vesper, ed. Frontiers of Entrepreneurship Research: The Proceedings of the Babson Conference on Entrepreneurship Research.

Hornaday, J.A., and J.Aboud. 1971. Characteristics of successful entrepreneurs. Personal Psychology 24, 2: 141-153.

Hornaday, J.A., and C. Bunker. 1970. The nature of the entrepreneur. Personal Psychology 23, 1: 47-54.

Hosking, D. M., and I. E. Morely. 1988. The skills of leadership. In J. G. Hunt, B. R. Baliga, H. P. Dachler, and C.A. Schriesheim, eds., Emerging Leadership Vistas. Lexington, MA: Lexington Books, 89-106.

House, R. J. 1977.A 1976 theory of charismatic leadership. In J. G. Hunt and L. L. Larson, eds., Leadership:The Cutting Edge. Carbondale, IL: Southern Illinois University Press, p. 189-207. 
House, R. J., and M. Baetz. 1979. Leadership: Some empirical generalizations and new research directions. In B. M. Staw, ed., Research in organizational behavior, vol.1. Greenwich, CT: JAI Press, 341-423.

Howard,A., and D. W. Bray. 1990. Predictions of managerial success over long periods of time: Lessons for the Management Progress Study. In K. E. Clark and M. B. Clark, eds., Measures of leadership. West Orange, NJ: Leadership Library of America, pp. 113-130.

Howell, J. M., and B. J.Avolio. 1993. Transformational leadership, transactional leadership, locus of control and support for innovation: Key predictors of consolidated-business-unit performance. Journal of Applied Psychology 78: 891-902.

Hull, D. L., J. J. Bosley, and G. G. Udell. 1980. Renewing the hunt for the heffalump: Identifying potential entrepreneurs by personality characteristics. Journal of Small Business Management 18: 11-18.

Jennings, R., C. Cox, and C. L. Cooper. 1994. Business elites. London: Routledge.

Joplin, J. R. W., and C. S. Daus. 1997. Challenges of leading a diverse workforce. The Academy of Management Executive 11, 3: $32-47$.

Kanter, R. M. 1989. When giants learn to dance: mastering the challenge of strategy, management, and careers in the 1990s. New York: Simon \& Schuster.

Kao, J. J. 1991. The Entrepreneur. Englewood Cliffs, NJ: Prentice Hall.

Kets de Vries, M. F. R. 1997. Creative leadership: jazzing up business. Chief Executive 121: 64-66.

Komives, J. L. 1972. A preliminary study of the personal values of high technology entrepreneurs. In A. C. Cooper and J. L. Komives, eds. Technical Entrepreneurship: A Symposium. Milwaukee: Center for Venture Management, $231-242$.

Kotter, J. P. 1996. Leading change. Boston, MA: Harvard Business School Press.

Lachman, R. 1980. Toward measurement of entrepreneurial tendencies. Management International Review 20, 2: $108-116$.

Leavitt, H. 1986. Corporate Pathfinders. New York: Penguin.

Liles, P. 1974. Who are the entrepreneurs? MSU Business Topics 22: 5-14.

Litzinger, W. D. 1965. The motel entrepreneur and the motel manager. Academy of Management Journal 8: 793.

Lussier, R. N., and C. F.Achua. 2004. Leadership:Theory, application, skill development, 2nd ed. Cincinnati: South-Western College Publishing.

McClelland, D. 1961. The achieving society. Princeton, NJ: Van Nostrand Co.

McClelland, D. C., and D. H. Burnham. 1976. Power is the great motivator. Harvard Business Review (March-April), $100-110$.

McClelland, D. C., and D. H. Burnham. 1994. Power is the great motivator. Harvard Business Review, Reprint 95108, $1-11$.

McGrath, R. G., I. C. MacMillan, and S. Scheinberg. 1992. Elitists, risk-takers, and rugged individualists? An exploratory analysis of cultural differences between entrepreneurs and non-entrepreneurs.Journal of Business Venturing 7: 115-135.

McMullen, J. S., and D.A. Shepherd. 2006, Entrepreneurial action and the role of uncertainty in the theory of the entrepreneur. Academy of Management Review 31: 132-152.

Mancuso, J. R. 1975. The entrepreneur's quiz. In C. M. Baumback and J. R. Mancuso, eds., Entrepreneurship and Venture Management. Englewood, NJ: Prentice-Hall, Inc.

Markman, G. D., and R.A. Baron. 2003. Person-entrepreneurship fit: Why some people are more successful as entrepreneurs than others. Human Resource Management Review 13, 281-301.

Mescon, T., and J. Montanari. 1981. The personalities of independent and franchise entrepreneurs:An empirical analysis of concepts. Journal of Enterprise Management 3, 2: 149-159.

Miller, D., and J. Toulouse. 1986. Chief executive personality and corporate strategy and structure in small firms. Management Science 32, 1389-1409.

Miller, D., M. F. R. Kets de Vries, and J-M.Toulouse. 1982. Top executive locus of control and its relationship to strategy-making, structure, and environment. Academy of Management Journal 25: 237-253.

Mumford, M. D., G. M. Scott, B. Gaddis, and J. M. Strange. 2002. Leading creative people: Orchestrating expertise and relationships. The Leadership 6.

Oneal, M. 1993. Just what is an entrepreneur? Business Week/Enterprise (October): 104-112. 
Palmer, M. 1971. The application of psychological testing to entrepreneurial potential. California Management Review 13,3: 32-39.

Rainey, H. G., and S.A. Watson. 1996. Transformational leadership and middle management:Towards a role for mere mortals. International Journal of Public Administration 19, 6: 763-800.

Respectfully Quoted:A Dictionary of Quotations Requested from the Congressional Research Service 2003. Washington DC: Library of Congress 1989; Bartleby.com 2003. www.bartleby.com/73/. February 4, 2008.

Rost, J. C. 1993. Leadership development in the new millennium. Journal of Leadership Studies 1, 1:92-110.

Roy, P. 1990/1991. Leadership and change in the 1990's. Optimum 21, 2: 7-12.

Schein, E. H. 1995. Leadership and organizational culture. In F. Hesselbein et al., The Leader of the Future. San Francisco: Jossey-Bass.

Schere, J. 1982. Tolerance of ambiguity as a discriminating variable between entrepreneurs and managers. New York: Academy of Management Proceedings 406.

Scherer, R. F. J. S. Adams, S. S. Carley, and F.A. Wiche. 1989. Role model performance effects on development of entrepreneurial career preference. Entrepreneurship Theory and Practice 13, 53-71.

Schrage, H. 1965. The R\&D entrepreneur: Profile of success. Harvard Business Review 43: 56-69.

Schulz, W. C., and C.W. Hofer, eds. 1999. Creating Value Through Skill-Based Strategy and Entrepreneurial Leadership. Pergamon.

Schumpeter, J.A. 1934. The Theory of Economic Development. Translated by R. Opie. Cambridge: Harvard University Press. Selznick, P. 1957. Leadership in administration: A sociological perspective. New York: Harper and Row.

Sexton, D. L., and N. Bowman. 1985. The entrepreneur:A capable executive and more. Journal of Business Venturing 1: 129-140.

Shane, S., E.A. Locke, and C. J. Collins. 2003. Entrepreneurial motivation. Human Resource Management Review 13, 2: 257-279.

Shapero,A. 1975. The displaced, uncomfortable entrepreneur. Psychology Today 9, 6: 83-88.

Shaver, K. G. 1995. The entrepreneurial personality myth. Business and Economic Review 41, 3: 20-23.

Shaver, K. G., and L. R. Scott. 1991. Person, process, choice:The psychology of new venture creation. Entrepreneurship Theory and Practice 16, 2: 23-45.

Stewart, W. H., Jr., and P. L. Roth. 2001. Risk propensity differences between entrepreneurs and managers: A meta-analytic review. Journal of Applied Psychology 86, 1: 145-153.

Stewart, W. H., Jr., W. E. Watson, J. C. Carland, and J. W. Carland. 1999. A proclivity for entrepreneurship: A comparison of entrepreneurs, small business owners, and corporate managers. Journal of Business Venturing 14, 2: 189-214.

Stogdill, R. M. 1948. Personal factors associated with leadership:A survey of the literature.Journal of Psychology 25:35-71.

Stogdill, R. M. 1974. Handbook of leadership: A survey of the literature. New York: Free Press

Swartz, N. 1997. The concepts of necessary and sufficient conditions. Department of Philosophy, Simon Fraser University. http://philosophy.hku.hk/think/meaning/swartz-nsc.pdf.

Timmons, J.A. 1999. New Venture Creation: Entrepreneurship for the 21st Century, 5th ed. Homewood, IL: Irwin McGraw Hill.

Timmons, J.A., L. E. Smollen, and A. L. M Dingee. 1985. New Venture Creation, 2nd ed. Homewood, IL: Richard D. Irwin.

Timmons, J.A., and S. Spinelli. 2004. New Venture Creation: Entrepreneurship for the 21st Century. New York: McGrawHill/Irwin.

Tracey, J. B., and T. R. Hinkin. 1998. Transformational leadership or effective managerial practices? Group and Organization Management 23, 3:220-236.

Vecchio, R. P. 2003. Entrepreneurship and leadership: Common trends and common threads. Human Resource Management Review 13:303-327. 
Vesper, K. H. 1982. Introduction and summary of entrepreneurship research. In C.A. Kent, D. L. Sexton, and K. H. Vesper, eds. Encyclopedia of Entrepreneurship. Englewood Cliffs: Prentice-Hall, xxxi-xxxviii.

Welsh, J.A., and J. P. White. 1981. Converging on characteristics of entrepreneurs. In K. H. Vesper, ed., Frontiers of

Entrepreneurship Research. Wellesley, MA: Babson Center for Entrepreneurial Studies, 504-515.

Welsh, J.A., and J. P. White. 1983. The Entrepreneur's Master Planning Guide. Englewood Cliffs, NJ: Prentice-Hall, Inc.

Yukl, G. 1998. Leadership in organizations 4th ed. Upper Saddle River, NJ: Prentice-Hall.

Yukl, G. 2002. Leadership in organizations 5th ed. Upper Saddle River, NJ: Prentice-Hall.

About the Authors

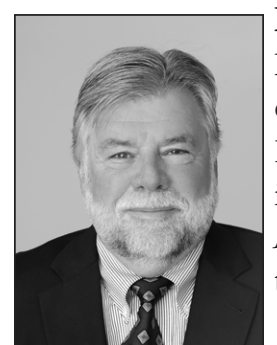

RICHARD C. BECHERER (Richard-Becherer@utc.edu) holds the Clarence E. Harris Chair of Excellence in Business and Entrepreneurship at the University of Tennessee at Chattanooga. He has had extensive experience both as an academic and as an entrepreneur. Dr. Becherer received his doctorate from the University of Kentucky and primarily teaches entrepreneurship courses. He has been published in numerous journals, including Entrepreneurship Theory and Practice, Journal of Small Business Management, Journal of Marketing, and Decision Sciences. Dr. Becherer was awarded a Fulbright grant to lecture on entrepreneurship topics at two universities in the Czech Republic during the spring of 2008.

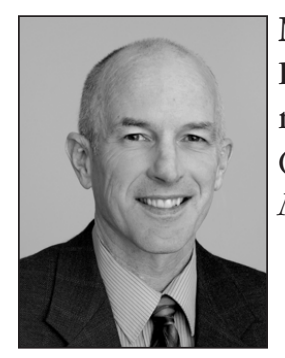

MarK E. Mendenhall (Mark-Mendenhall@utc.edu) holds the J. Burton Frierson Chair of Excellence in Business Leadership in the College of Business at the University of Tennessee, Chattanooga. He has coauthored numerous books, the most recent being Global Leadership: Research, Practice and Development (Routledge), and has been published in numerous journals, including Academy of Management Review, Sloan Management Review, and Journal of International Business Studies.

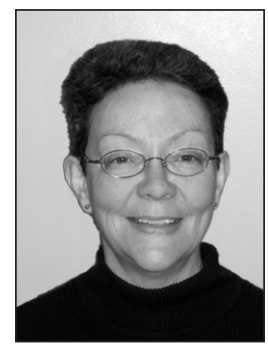

KAREN FORD EICKHOFF (keickhof@utk.edu) is a doctoral student in business administration at the University of Tennessee, Knoxville. She taught strategic management, organizational behavior, and human resource management at the University of Tennessee, Chattanooga, for more than 20 years and served in board leadership roles for a major hospital and the Tennessee Hospital Association. Her research interests include board and executive leadership in traditional and entrepreneurial organizations. 